\title{
The Effect of Using Learning Portal on Primary School Students in the Subject of Design and Technology
}

\author{
Azita Binti Ali*, Intan Shariena Binti Abdul Rashid, Ea Suk Yong \\ Faculty of Technical and Vocational Education, Parit Raja, Malaysia
}

Received August 31, 2019; Revised November 24, 2019; Accepted December 3, 2019

\begin{abstract}
Copyright@2019 by authors, all rights reserved. Authors agree that this article remains permanently open access under the terms of the Creative Commons Attribution License 4.0 International License
\end{abstract}

\begin{abstract}
Design and Technology (DST) were introduced at the Primary School as more emphasis is being placed on technical and vocational skills nowadays. However, the use of conventional teaching methods and the lack of teaching aids have triggered students' low achievement in the DST subject. This study was conducted to identify the effect of using DST learning portal on students' achievement compared with using conventional teaching method. A DST learning portal was developed and used as an independent variable in this study. A total of 32 year 4 students from a Primary School were selected as respondents by purposive sampling method. This study is quasi-experimental research which uses pre and post-test as an instrument to identify the achievement of students before and after using different learning methods in the DST subject. In addition, questionnaire and observation checklist were used to collect students' perceptions about the usability of DST learning portal. The data were analysed descriptively by using quantitative approach. The results of the independent t-test showed that there was no significant difference in pre-test achievement between treatment group $(\mathrm{M}=23.8, \mathrm{SD}=12.6)$ and control group $(\mathrm{M}=25.0, \mathrm{SD}=14.1)$; $(30)=0.64, \mathrm{p}=$ 0.79 , while Mann Whitney $U$ test results showed that the post-test achievement of treatment group was higher than the control group after using DST learning portal $(\mathrm{U}=7.500$, $\mathrm{p}$ $=.000$ ). The level of usability of the learning portal was very high according to the score obtained from the questionnaire (88.15\%) and the checklist (84\%). These findings show that the DST learning portal has a very high level of usability and the use of portal can significantly improve students' achievement in DST subject.
\end{abstract}

Keywords Design and Technology, Learning Portal, Usability, Students’ Achievement

\section{Introduction}

Aligning with implementation of the Malaysia Primary School Standard Curriculum, Design and Technology Subject (DST) was used as a substitute for the Living Skills subject. This subject focuses on preparing 4, 5 and 6 year pupils in primary schools with basic knowledge and skills that enable them to gain knowledge, master the basis of practical skills, design skills and apply the technology towards producing critical, creative and innovative students. (Bahagian Pembangunan Kurikulum, 2013).

The 21st century learning concepts are emphasized throughout the new curriculum implementation. In this context, teachers need to apply various types of teaching methods to ensure students learn in an effective way. However, there are still some teachers who practice conventional teaching methods by using chalk and talk strategy (Abu Bakar, 2008). This statement is also supported by Sutaji (2015) which emphasizes that there are still many educators who are more likely to use conventional teaching methods in teaching and learning process.

Additionally, the use of conventional teaching methods makes it difficult for students to concentrate and feel motivated in learning process involving teacher-centered methods. This is supported by the study of Jumiran (2014) which found that conventional teaching methods have led to lower student motivation in Mathematics learning and this also affects the level of student achievement. The study of Tukiran, Ariffin and Mohd Rozi (2012) supports this statement by emphasizing that learning activities involving conventional methods cause students to feel bored and trigger the student's low achievement. 
In the context of education, motivation is important as it determines the effectiveness of teaching and learning. Therefore, motivation is often related to students' achievement. The conventional teaching method will cause the students to lose interest towards a subject and subsequently fail to master the subject. The study of Ibrahim (2015) supports the statement by proving the use of the chalk and talk method had caused most of the students to be unmotivated to learn and to have low achievement in the Malay Language subject. According to Kassim and Zakaria (2013), teacher-centered approaches can limit the potential development of students and disrupt students' learning performance.

Additionally, the hand tools in the DST workshop in school are unable to accommodate the needs of the students. Indeed, teachers can use it in the teaching and learning process to replace stimulate active learning environment among students. However, Supramaniyam (2015) highlighted that the DST workshop at school is lack of hand tools. As all of us know that, DST is an active-oriented subject of hands-on learning and closely related to human life. Insufficient supply of hand tools in school may cause students to be unable to understand and master the skills in this subject.

In addition, failure in providing hand tools and conventional teaching methods has led to the low academic achievements among students. This is because they are hard to understand the concept or master the skills just by imagination without any demonstration or practical session. (Ashwin, 2004). This scenario coincides with Madar (2009) who points out that students are having problems understanding the concept or mastering a skill due to the absence of appropriate equipment. This statement was also supported by Razali (2001) where the absence of appropriate hand tools is the cause of students facing serious problems in understanding the concept and mastering the skills.

Conventional teaching method is no longer in line with the agenda of education in this era of globalization. Tukiran,
Ariffin and Mohd Rozi (2012) emphasize that the use of conventional teaching methods will cause students to feel bored and unmotivated in learning. The use of learning portal is an alternative way to overcome the problem. Learning portal can help provide learning materials which combine different types of media such as text, animation, graphics, audio and video to maintain students' attention and improve their achievement. The use of learning portals not only allows teachers to deliver knowledge effectively, but also stimulates active learning environment among students.

The use of learning portal may ease teachers to design learning content and conduct learning activities effectively. It was found that the level of achievement in DST among Year 4 students in a primary school was low due to the use of conventional teaching methods without any teaching aids. Therefore, it is desirable that a study be conducted to identify the effectiveness of using learning portals to raise the students' achievement in the DST subject among year 4 students. Thus, this study was conducted to develop a learning portal, then study the effect of its use on student achievement in DST and to identify student perceptions on the usefulness of the learning portal.

\section{Methodology}

In this study, quasi-experimental design is used and it involves a control group and a treatment group. Comparisons were made first based on the pre-test achievements between treatment group and control group. After that, the treatment group used DST learning portal as an intervention whereas the control group doesn't receive any intervention. The achievement of both groups was compared after eight weeks of learning to see the effect of using the learning portal on students' achievement. Thus, two different learning methods were used as the independent variables in this study while the student's achievement in Design and Technology subject was determined as the dependent variable. The design of this study is shown in figure 1 as follow.

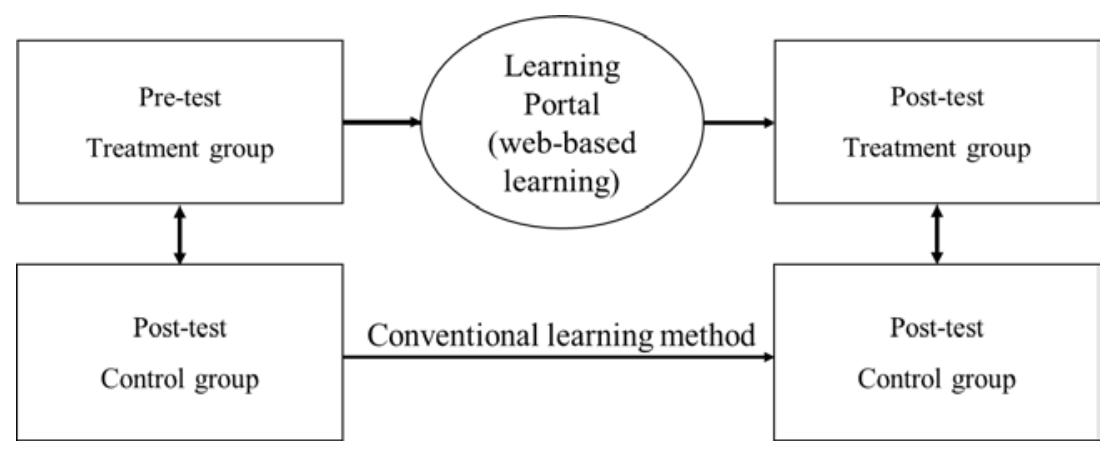

Figure 1. Quasi-experimental design in this study 


\subsection{Population and Sampling Method}

This study involved 32 Year 4 students from a National Primary School in Batu Pahat district, Johore State. Purposive sampling method is used to determine the sample of the study. Researchers chose a class of 32 pupils which had low achievement in Design and Technology subject as the sample of this study. Among them, 16 students were grouped as treatment groups and 16 students were grouped as control groups. In the sampling process, the researcher ensured that the academic achievement between the treatment group and the control group was equivalent to avoid any bias in this study.

\subsection{Research Instruments}

This study uses pre and post-test, checklist and questionnaire to collect data and analyse data. Pre and post tests were used to compare the students' achievement in Design and Technology (DST) before and after the use of learning portals. Besides, researchers used questionnaire to collect data on the usability of the DST learning portal in this study, as perceived by treatment group students. Meanwhile, the observation checklist is used to support students' perception of the usability of DST learning portal.

For the pre and post-test, a total of 15 items were developed by the researchers. Only 10 items where the difficulty index was between 0.21 and 0.80 and the discrimination index above 0.21 was accepted as pre and post-test items in this study. The questionnaire in this study was adapted from Qureshi and Irfan (2009) on the evaluation of the usability of learning portals. A total of 20 items were developed to assess the usability of learning portals in teaching and learning for Year 4 Design and Technology. To maintain the validity and reliability of this study, pilot studies were conducted to identify the reliability of the questionnaire. The Alpha Cronbach value gained is 0.717 . Based on the interpretation of the Alpha Cronbach value by Bond and Fox (2007), this finding showed that the items in the questionnaire are good and acceptable to use in real studies.

Other than questionnaire, researchers used a checklist to record the behaviour or actions of students indicating the usability of the learning portal. According to Idris (2013), a checklist is a tool used by the researchers to record the frequency of behaviours, words or actions of the student. In this study, the checklist has been used along the learning process of the treatment group to serve as a support for the data gained from the questionnaire on the usability of the learning portal.

\subsection{Data Analysis}

In this study, researchers used an independent t-test and Mann Whitney U test to identify whether there was a significant difference between treatment group and control group in students' achievement before and after using learning portals. Besides, frequency and percentage score were used to analyse the data on the usability of the learning portal as perceived by students.

\section{Results}

The total number of respondents in this study was 32 people. To avoid any bias in this study, the number of respondents distributed in both groups was the same, where control groups and treatment groups had 16 respondents respectively. Both control and treatment groups have the equivalent number of male and female students, namely 7 male students and 9 female students, as shown in Table 1.

Table 1. Respondent demographics

\begin{tabular}{cccc}
\hline Group & Male & Female & Percentage \\
\hline Treatment Group & 7 & 9 & 50 \\
\hline Control Group & 7 & 9 & 50 \\
\hline
\end{tabular}

Independent t-test was conducted to study the differences in the pre-test achievement between the treatment group and the control group before using different learning methods. The study found that there was no significant difference in pre-test achievement between the Treatment Group ( $\mathrm{M}=$ 23.8, $\mathrm{SD}=12.6)$ and Control Group $(\mathrm{M}=25.0, \mathrm{SD}=14.1)$; $\mathrm{t}$ $(30)=0.64, p=0.79$. In conclusion, there was no significant difference in pre-test achievement between the treatment group and the control group before using the Design and Technology (DST) learning portal. The result was shown in Table 2 as follow.

Table 2. Independent t-test result for pre-test achievement between two groups

\begin{tabular}{|c|c|c|c|c|c|c|c|}
\hline \multicolumn{2}{|c|}{} & \multicolumn{2}{|c|}{$\begin{array}{c}\text { Levene's Test for Equality of } \\
\text { Variances }\end{array}$} & t-test for Equality of Means \\
\cline { 3 - 8 } & & F & Sig. & t & df & Sig. (2-tailed) & Mean Difference \\
\hline Pre-test & Equal variances assumed & .228 & .636 & -.264 & 30 & .793 & -1.250 \\
\hline
\end{tabular}


Mann Whitney U test has been conducted to identify the differences in the post-test score between the treatment group and the control group after using the learning portal. From the results obtained, it can be concluded that the post-test score in the treatment group is higher than the control group $(U=7.500, p=.000)$. In conclusion, there was a significant difference in the post-test score between the treatment group and the control group. The treatment group gained a higher achievement than the control group after using the Design and Technology learning portal. The result of Mann Whitney U test was shown as in Table 3.

Regarding the usability of DST learning portal, most respondents agreed with 20 items in the questionnaire with a percentage score of $88.15 \%$. Only 16 students from the treatment group using the Design and Technology (DST) learning portal were involved to give their perception on the usability of the DST learning portal. Table 4 shows the usability of learning portals according to students' perception.

Table 3. Mann-Whitney U test result for post-test achievement between two groups

\begin{tabular}{|c|c|}
\hline & Post-test \\
\hline Mann-Whitney U & 7.500 \\
\hline Wilcoxon W & 143.500 \\
\hline Z & -4.609 \\
\hline Asymp. Sig. (2-tailed) & .000 \\
\hline a. Grouping Variable: Groups & \\
\hline
\end{tabular}

Table 4. Usability of learning portals according to students' perception

\begin{tabular}{|c|c|c|c|c|c|}
\hline \multirow{2}{*}{ Item } & \multirow{2}{*}{ Statement } & \multicolumn{2}{|c|}{ Yes } & \multicolumn{2}{|c|}{ No } \\
\hline & & $f$ & $\%$ & $f$ & $\%$ \\
\hline 1. & Instructions in this portal are easy to understand. & 15 & 93.8 & 1 & 6.3 \\
\hline 2. & The text in this portal is easy to read. & 15 & 93.8 & 1 & 6.3 \\
\hline 3. & I like the colourful text in the portal. & 13 & 81.3 & 3 & 18.8 \\
\hline 4. & I like the colourful background in the portal. & 10 & 62.5 & 6 & 37.5 \\
\hline 5. & The pictures in this portal caught my attention. & 14 & 87.5 & 2 & 12.5 \\
\hline 6. & Learning is fun with the presence of background music. & 12 & 75.0 & 4 & 25.0 \\
\hline 7. & The videos in this portal are very interesting. & 14 & 87.5 & 2 & 12.5 \\
\hline 8. & The videos in this portal help me in learning. & 16 & 100 & 0 & 0 \\
\hline 9. & The notes provided are easy to understand. & 14 & 87.5 & 2 & 12.5 \\
\hline 10. & The notes provided help me to revise what I've learned. & 15 & 93.8 & 1 & 6.3 \\
\hline 11. & The navigation buttons are user-friendly. & 13 & 81.3 & 3 & 18.8 \\
\hline 12. & This portal is easy to access. & 14 & 87.5 & 2 & 12.5 \\
\hline 13. & This portal caught my attention. & 16 & 100 & 0 & 0 \\
\hline 14. & This portal motivates me in learning DST. & 16 & 100 & 0 & 0 \\
\hline 15. & This portal makes it easy for me to master the learning. & 15 & 93.8 & 1 & 6.3 \\
\hline 16. & The quizzes help to improve my knowledge retention. & 15 & 93.8 & 1 & 6.3 \\
\hline 17. & The formative assessments help reinforce learning. & 16 & 100 & 0 & 0 \\
\hline 18. & I like to learn by using this learning portal. & 16 & 100 & 0 & 0 \\
\hline 19. & I am interested in using learning portals for other subjects. & 12 & 75.0 & 4 & 25.0 \\
\hline 20. & $\begin{array}{l}\text { I choose the learning portal as a learning method compared to a regular learning } \\
\text { method. }\end{array}$ & 11 & 68.8 & 5 & 31.3 \\
\hline
\end{tabular}

$\mathrm{N}=20$, percentage score $=88.15 \%$. 
In addition, the percentage score obtained through the checklist about the usability of the learning portal was $84 \%$. The findings of the data analysis from the questionnaire and the checklist showed a score of $88.15 \%$ and $84 \%$ respectively. The results showed a very high degree of usability for DST learning portal according to students' perception.

\section{Findings and Discussions}

Before using the Design and Technology (DST) learning portal, the students' achievement in the DST subject was low where the mean score in treatment group was 23.8 marks, while the control group was 25.0 marks. These two groups used conventional learning methods before this study was conducted. This proves that the use of conventional learning methods without using appropriate teaching aids will result in a low level of students' achievement.

There was a significant difference in the achievement of students between the treatment group and the control group after using the learning portal. The academic achievement of the two groups at the beginning of this study was the same before the independent variables were manipulated. The difference in post-test achievement proved that the use of DST learning portal in teaching and learning has improved the treatment group's achievement from 23.75 (pre-test mean score) to 68.13 (post-test mean score).

At the end of this study, the achievement of students using the DST learning portal was higher than the control group students who followed conventional learning. This is in line with Sardi@Mohd Yusop's (2009) study that proved that the use of the My-Arab Portal has increased the level of student achievement as well as supported the acquisition of students effectively in the context of reviewing, understanding of new knowledge, training and stimulating memory. The effective use of learning portals incorporating technology and multimedia is also supported in the study of Sutaji (2015) which emphasizes that the teaching and learning process which is assisted by the use of technology and interactive multimedia materials can help convert abstract theories or information into dynamic and interactive learning patterns.

Indeed, the use of learning portals can improve students' performance effectively compared to conventional learning methods. This statement is supported by Hussin, Rasul \& Abd Rauf (2013) who agreed that the use of learning portals can help students to master a concept more effectively. Additionally, Mohd Najib, Abu Bakar and Othman (2017) point out that the use of learning portals in the teaching and learning process can provide a conducive learning environment and at the same time give a positive impact in creating quality learning. In conclusion, educators should take steps in practising the use of learning portals to improve the effectiveness of teaching and learning, as well as attract students' interest and concentration through intense planning.
In order to design and develop an effective learning portal, the usability of the learning portal shall be subject to the prior consideration. This is to prevent any disturbance or technical errors that may interrupt the teaching and learning process. In this study, researchers developed a DST learning portal and used it as intervention learning method for treatment group. Students' perceptions about the usability of DST learning portal were then collected through questionnaire and checklist, then analysed by using the percentage score obtained.

The findings showed that major respondents agreed with 20 items on the usability of learning portal with a percentage of $88.15 \%$. Among the 20 items, 100\% respondents agreed on the 8th, 13th, 14th, 17th and 18th item. All the respondents agreed that "the videos in this portal help me in learning," "formative assessments helped reinforce learning," "this portal caught my attention", "this portal motivates me in learning DST" and " I like to learn by using this learning portal.". The perception of students pointed out that the videos and the formative assessments provided on each topic can help them to reinforce the knowledge they learnt. Videos that combine multimedia elements such as text, animations, graphics and audio were used in the learning portal as the main inputs where students will acquire all the knowledge through it. Zainul, Abdul Malek and Basharudin (2017) have proven that using videos in teaching and learning can have a positive impact on students' academic achievement in their study. In addition, the formative assessments in the learning portal play an important role as reinforcement learning, as well as an assessment tool on students' mastery of knowledge. Othman (2016) describes the importance of the use of learning assessments in the teaching and learning process as it played a role in reinforcing students' learning and improving the effectiveness of teaching and learning process towards achieving learning objectives.

In addition, all of the respondents agreed with statements such as "this portal caught my attention", "this portal motivates me in learning DST" and " I like to learn by using this learning portal". These statements prove that learning portal that developed based on the ARCS model is attractive and can motivate students in learning DST effectively. Previous studies have shown that the use of the learning portal can boost students' motivation in learning. Che Wan (2007) in his study proves that the use of the learning portal in teaching and learning has improved students' motivation in learning. The findings of Mohd Sadri (2010) also support these statements by proving the use of interactive learning portals had successfully maintained students' concentration in the learning session.

However, among the 20 items in the questionnaire, the 4th item showed the lowest percentage score where only $62.5 \%$ (10) respondents agreed that "I like the colourful background in the portal". In the DST learning portal, each section and each page had a very colourful background. According to Yoes (2014), plenty of colours will influence the 
concentration and understanding of the students in the learning process. Based on these findings, it can be concluded that the colourful background of the learning portal is less favourable to the user. This is because the colourful background makes the students' concentration distract away from the learning content, and even worse, they will only focus on the colourful background. Therefore, educators should use colours precisely in the design and development of materials to avoid distracting the concentration of the students.

\section{Conclusions}

It can be concluded that the use of the Design and Technology (DST) learning portal could significantly improve the achievement of Year 4 students in DST. Before the study was conducted, the achievement of both the treatment group and the control group was equivalent. However, after researchers manipulate the independent variables, there is a significant difference in achievement between the treatment group and the control group, in which the treatment group achieves higher scores than the control group. In addition, the majority of respondents from the treatment group agreed that the usability of the learning portal in this study was very high. This is because the use of multimedia, interactive activities, as well as portal designs that align with the learning objectives, had given a positive impact on creating effective learning among students. Thus, it can be concluded that the learning portal used in this study has a very high level of usability and can significantly improve the achievement of Year 4 students in DST.

\section{REFERENCE}

[1] Abu Bakar, M. S. (2008). Pembangunan perisian pengajaran berasaskan model konstruktivisme needham lima fasa bagi tajuk keelektrikan dalam matapelajaran sains sekolah rendah. Skudai: Universiti Teknologi Malaysia.

[2] Ashwin (2004). Kesan grafik dalam pembelajaran di bilik darjah. Bangi: Universiti Kebangsaan Malaysia.

[3] Bahagian Pembangunan Kurikulum (2013). Dokumen standard kurikulum dan pentaksiran reka bentuk dan teknologi tahun 4. Putrajaya: Kementerian Pendidikan Malaysia.

[4] Bond, T. G., \& Fox, C. M. (2007). Applying the Rasch model: Fundamental measurement in the human sciences (2nd ed.). London: Lawrence Erlbaum.

[5] Che Wan, C. R. I., (2007). Penggunaan laman web dalam kalangan guru pendidikan islam di daerah Seremban. Bangi: UKM.

[6] Hussin, N., Rasul, M. S., \& Abd Rauf, R. (2013). Penggunaan laman web sebagai transformasi dalam pembelajaran dan pemudahcaraan pendidikan Islam. The Online Journal of
Islamic Education, 1(2), 58-73.

[7] Ibrahim, S. (2015). Motivasi pelajar dalam pembelajaran Bahasa melayu menggunakan teknologi multimedia pada abad ke-21. Universiti Malaysia Sarawak: Master. Thesis.

[8] Idris, N. (2013). Penyelidikan dalam pendidikan. Kuala Lumpur: Mc Graw Hill.

[9] Jumiran, M. N. (2014). Kesan teknik "HunTTO Square” terhadap pencapaian pelajar bagi mata pelajaran matematik di sekolah rendah. Universiti Tun Hussein Onn Malaysia: Master. Thesis.

[10] Kassim, N. \& Zakaria, E. (2013). Integrasi Kemahiran Berfikir Aras Tinggi dalam Pembelajaran dan pemudahcaraan Matematik: Analisis Keperluan Guru. Jurnal Pendidikan Matematik, 3(1), 1 - 12.

[11] Madar, A. R. (2009). Keberkesanan animasi grafik dalam kalangan pelajar berbeza gaya kognitif dan kebolehan visualisasi spatial di politeknik. Universiti Teknologi Malaysia: Ph.D. Thesis.

[12] Mohd Najib, H., Abu Bakar, N. R., Othman, N. (2017). E-pembelajaran dalam kalangan pelajar di sebuah institusi pengajian tinggi Selangor. Attarbawiy: Malaysian Online Journal of Education, 1(1), 74-82.

[13] Mohd Sadri, Z. (2010). Pembangunan laman web topik rukun haji dan umrah tingkatan empat berdasarkan teori konstruktivisme. Universiti Teknologi Malaysia: Bachelor. Thesis.

[14] Othman, A. (2016). Pengetahuan, kemahiran dan amalan guru membina item kemahiran berfikir aras tinggi (kbat) dalam instrumen pentaksiran pembelajaran. Universiti Tun Hussein Onn Malaysia: Master. Thesis.

[15] Qureshi, K. M. \& Irfan, M. (2009). Usability evaluation of e-learning applications, A case study of It's Learning from a student's perspective. Blekinge Institute of Technology: Master. Thesis.

[16] Razali, Z. B. (2001). Pembelajaran berbantu multimedia: Implikasi pembelajaran subjek kejuruteraan mekanikal. Kolej Universiti Kejuruteraan Utara Malaysia: Master. Unpublished thesis.

[17] Sardi @ Mohd Yusop, J. (2009). Pembelajaran nahu dalam Bahasa Arab Komunikasi menggunakan aplikasi multimedia berasaskan web. Universiti Malaya: PhD. Thesis.

[18] Sardi, J. \& Abdul Majid, M. A. (2004). e-Pembelajaran: Tinjauan Penggunaan Kosa Kata dan Nahu dalam Laman Web Percuma dan Implikasinya Terhadap Pengajaran dan Pembelajaran Bahasa Arab (Monograf Penyelidikan). Institut Penyelidikan, Perundingan \& Pengkomersilan, Universiti Teknologi MARA.

[19] Supramaniyam, V. (2015). Penggunaan teknologi maklumat dan komunikasi (TMK) dalam kalangan guru guru subjek kemahiran hidup di sekolah rendah luar bandar negeri Johor. Universiti Tun Hussein Onn Malaysia: Master. Thesis.

[20] Sutaji, S. S. (2015). Kesan penggunaan koswer multimedia animasi visual terhadap pencapaian pelajar dalam mata pelajaran matematik. Universiti Tun Hussein Onn Malaysia: Master. Thesis.

[21] Tukiran, N., Ariffin, J. A. M., \& Mohd Rozi, S. H. (2012). 
Teori Kecerdasan Pelbagai Untuk Meningkatkan Penglibatan Aktif Pelajar Di Dalam Kelas. Retrieved on September 2018 at

https://www.academia.edu/27086449/teori_kecerdasan_pelb agai_untuk_meningkatkan_penglibatan_aktif_pelajar_di_dal am_kelas

[22] Yasak, Z., Mohamad, B., Esa, A. \& Shabuddin, S. (2009). Kaedah pengajaran berasaskan laman web terhadap pelajar Diploma Kejuruteraan Elektrik Mekatronik di politeknik. Persidangan Kebangsaan Pendidikan Sains dan Teknologi. Malaysia. Retrieved on October 2018 at http://eprints.uthm.edu.my/2689/1/28._Pendidikan_Sains_da n_Teknologi_2009_3_.pdf

[23] Yoes, B. (2014). Pengaruh warna pada pembelajaran. Retrieved on November 2018 at http://menofschool.blogspot.com/2014/05/pengaruh-warna-p ada-pembelajaran.html

[24] Zainul, A., Abdul Malek, A. \& Basharudin, N. A. (2017). Keberkesanan penggunaan video pembelajaran interaktif untuk kursus embedded system application. E-Proceedings iCompEx17. Malaysia. Retrieved on November 2018 at http://upikpolimas.edu.my/conference/index.php/icompex/ic ompex17/paper/viewFile/54/41 